\title{
Alternative Sources of Funding For Free Day Secondary Education (FDSE) In Public Schools in Kisii Central District, Kisii County, Kenya
}

\author{
Kennedy Nyambeche Getange ${ }^{1}$, Jacob Machogu Onkeo ${ }^{2}$ and John Aluko \\ Orodho $^{3}$ \\ Lecturer in the school of Education, Kisii University, Kenya. \\ Doctorate student in the Department of Educational Management, Policy, and Curriculum Studies, School of \\ Education, Kenyatta University, Kenya. \\ Associate Professor and supervisor of Kennedy Nyambeche and Department of Educational Management, \\ Policy, and Curriculum Studies, School of Education, Kenyatta University, Kenya
}

\begin{abstract}
The thrust of this paper was to examine the alternative sources of funding for the free Day Secondary Education (FDSE) policy in public schools in Kisii Central District, Kisii County, Kenya. It is concerned with one main question: How adequate is the current government funding mechanism? To answer the question, the paper sets out to achieve three objectives: i) To profile the current trends in unit funding of all levels of education in the country, and ii) to examine the alternative funding strategy for public day secondary education in Kisii Central District, Kisii County, Kenya. The source of data for the paper was a combination of secondary data through desk literature review and primary data from a sample of 148 respondents drawn across various education stakeholders in the study locale. The major finding was that while on the one hand the Government of Kenya through the Ministry of Education was implementing the FDSE policy; on the other hand, the education sector in the study locale was still fraught with myriad of finance related challenges .The funds meant to fast track the FDSE policy are grossly inadequate and irregularly remitted to schools. This has forced the school managers to device alternative sources of financing education which is currently constraining the already poor parents. It is recommended that day secondary schools in Kenya should device more user-friendly modes of generating extra funds from income generating activities that do not burden parents of children from poor socio-economic backgrounds. [246 words]
\end{abstract}

Key Words: Education policies, secondary education, Free Day Secondary Education (FDSE), Equity, access, quality, Kisii Central District, Kenya.

\section{Introduction: Background Information}

In tandem with international conventions and protocols that encourage governments to provide universal education to its citizens, the Government of Kenya launched Free Primary Education(FPE) in 2003 and free day secondary education (FDSE) in 2008 ( Orodho,2013,2014; Republic of Kenya,2013). The objective of these policy initiatives was to increase access and to cushion poor households by abolishing school fees (Njeru \& Orodho, 2003). As a result, enrolment in public primary schools rose from 5.9million in January 2003 to 9.4 million in 2010, an increase of 59.32\% in GER (Republic of Kenya/UNESCO, 2012). In terms of financial resources, a total of Ksh 63.4 billion has been spent on the program through purchasing instructional materials, as well as general-purpose expenses/recurrent expenditures through a capitation grant of Ksh 1,020 per child in 19,833 public primary schools (Orodho, 2014; Republic of Kenya, 2012a, 2012b).

The launch of Free Secondary Education (FSE) in 2008 was meant to address illiteracy, low quality education and low completion rates at the secondary level, high cost of education and poor community participation (Republic of Kenya, 2005).Unlike the FPE initiative, which had reference to enormous conventions, resolutions and literature, free secondary education initiative could have been triggered by the politically charged climate that engulfed the country during the 2007 general election which implied that the country may not have been very prepared for its implementation( Orodho,2014). However, there was government commitment to increase transition rate from primary to secondary by seventy percent in all districts (Republic of Kenya, 2013; Orodho, 2014).

According to the Free Secondary Education policy, the government was expected to meet the tuition fees of KShs 10,265 per student, while the parents were required to meet other requirements like lunch, transport and boarding fees for those in boarding schools, besides development of approved school projects. This was in line with the government commitment to ensure that regional special needs and gender disparities were addressed (Ohba, 2009). These efforts were a positive move towards the realization of the Millennium Development Goals (MDGs) and Education for All. 
The introduction and subsequent implementation of policy on Free Day Secondary Education in 2008 in Kenya has made education sector budget in the country to substantially increase over the years (Republic of Kenya, 2012a, 2012b). The education sectors public spending was allocated colossal funding which increased from Khs.92.2 billion (equivalent to US\$ 1.08 billion) in 2005/2006 to Ksh.169 billion (US \$1.88 billion) in 2009/2010 fiscal year to meet the new demands of the policies (Republic of Kenya, 2010a,2010b; Orodh,2014).On average, the education sector accounted for 28 percent of the aggregate public expenditure in 2005/2006 and dropped marginally to 26 percent in 2009/2010 fiscal years (Republic of Kenya, 2013). The country's education expenditure as a percentage of the Gross Domestic Product (GDP) has remained fairly constant ranging from 6.1 percent in 2005/2006 to 6.2 during the 2009/2010 financial year (Republic of Kenya, 2012a). These efforts to devote meaningful funding to education is justified against the backdrop that available evidence from literature review suggests a positive and significant correlation between indicators of quality and financial allocation (Oketch \& Ngware, 2012; Brookings Institution, 2013). However, recent studies on financing in Kenya indicate that there are serious finance related constraints affecting effective implementation of the policy in Kenya (Orodho, 2014; Republic of Kenya/UNESCO, 2012). It is against this background that this study sought to examine the alternative sources of funding public secondary schools in Kisii Central District, Kenya.

\section{State Of The Art Review}

Based on the lessons leant during the implementation of FPE, it would be expected that implementation of free secondary education was to be faced with a myriad problems. Research on FPE indicated that there were many challenges facing its implementation (Republic of Kenya, 2005; UNESCO, 2005a, 2005b). For example, UNESCO (2005a) carried out an assessment of the Free Primary Education programme in Kenya in 2005. The assessment found out that some of the major challenges facing free primary education initiative were increased student numbers; shortage of teachers; lack of clear guidelines on admission; lack of consultation with teachers and parents; delay in disbursement of funds by the government; and expanded roles for head teachers. The recent assessment of basic education in Kenya by Republic of Kenya/UNESCO (2012) and Orodho (2014) similarly documented that despite milestones achieved towards attaining UBE by 2015, Kenya still faces a number of finance related challenges that are negatively impacting on quality and equity of educational provision in the country.

The foregoing notwithstanding, the strategies to generously finance education system in Kenya is hinged on the philosophy, vision, mission and target goals pursued through clearly stated objectives( Republic of Kenya,2012a, 2013) .Furthermore, the Ministry of Education in Kenya is guided by the National Philosophy, which places education at the centre-stage of the country's human and economic development strategies( Republic of Kenya,2013). Thus, the education system focuses on the acquisition of knowledge and skills as well as provision of lifelong learning (Republic of Kenya, 2013; United Nations, 2013). In line with the current United Nations (2013) and other educationally relevant international conventions and protocols which Kenya is a signatory to, the education in the country emphasizes provision of a holistic, quality education and training that promotes the cognitive, psychomotor and affective domains of learners, instilling values such as patriotism, equality of all human beings, peace, security, honesty, humility, mutual respect, tolerance, cooperation and democracy, through education ( Odhiambo,2012; Republic of Kenya, 2012a, 2012b,2013; United Nations,2013). Ultimately the overall vision of education service provision in the country is to have a globally competitive quality education, training and research for Kenya's sustainable development. To achieve this, the Ministry has endorsed Vision 2030 and shall focus education and training towards achieving the goals of the Vision (Republic of Kenya, 2012a, 2013).

\section{Statement of the Problem}

The introduction of free day secondary education has also seen an increase in the transition rate, surpassing the national target of $70 \%$ of 2008 to stand at $72 \%$ in 2010/2011.The capitation grant is Ksh 10,265/ per student per annum, covering tuition and general purpose expenses. Parents cater for boarding expenses, lunches, uniform and other development expenses. Enrolment increased steadily from 1.3 million in 2008 to 1.8 million students in 2011. Up to the financial year 2009/2010 the MoE disbursed Ksh 55,540,140,323 billion to $1,605,364$ students in 6,009 schools in support of this programme. Other ongoing programmes to support free schooling initiatives include: support to low-cost primary boarding schools in ASALs; special capitation grants for special needs education at Kshs. 2000 per child over and above the normal capitation of 1020; providing support to non-formal schools for procurement of teaching-learning materials to institutions offering the primary school curriculum in slum areas, construction and rehabilitation of classrooms; special grants for expanding educational opportunities in ASAL areas for the construction and equipping of schools, as well as improving school health and nutrition in collaboration with Ministry of Public Health and Sanitation and the World Food 
Programme; creating an education bursary for the needy, and a bursary for girls in ASAL and in high poverty areas, as well as for laboratory and ICT equipment; amongst other noble initiatives.

When free day secondary education was introduced in 2008, the ministry quickly registered progress in enrolment at the secondary school level. Secondary gross enrolment rates increased by 278,828 while net enrolment decreased by 285,109 in 2008. During the same year, the gross enrolment rate for boys (46.3\%) was higher than that of girls estimated at 38.8 percent (Republic of Kenya/UNESCO, 2012). Despite these milestones achieved towards attaining UBE by 2015 , Kenya still faces a number of challenges, some of them significant in improving access, equity, quality and relevance of education, especially in the urban slums and ASAL regions. The overall problem addressed in this paper is that there appears to be some unfinished business in the funding mechanism of the PDSE policy as manifested in lack of a clear picture and understanding of how this noble FDSE policy is currently being implemented and the emerging funding related challenges as well as their cumulative impact on access to, equity and quality of educational provision in the country.

\subsection{Purpose and Objectives}

The purpose of this study was to examine the alternative sources of funding public day secondary schools in Kisii Central District, Kenya. The study had two objectives, first to profile the current public spending on education by level of education in Kenya and second, to examine the alternative funding of public day secondary schools in Kisii Central District, Kenya.

\section{Theoretical Framework}

This paper is framed by the Capital Theory of School Effectiveness and Improvement developed by Hargreaves (2001).Thus, Hargreaves (2001) developed a theory of school effectiveness and improvement based on: outcomes, both cognitive and moral; leverage, which is the relation between teacher input and education output; intellectual capital, which is the sum of the school's knowledge and experience; and social capital, that is, networks of trust and collaboration. In this theory, Hargreaves (2001) argues that the conventional model of measuring school effectiveness (and by extension improvement) is an inadequate tool for the analysis of school success and failure. Hargreaves (2001) posits that the concept of 'school ethos' helps to make sense of the correlation between a number of school processes, but it does not automatically allow one to test the model in detail, or to predict the performance of a school from any close analysis of identifiable factors. Nonetheless, he proposes a new theoretical model of schools, which provides a working model both of effectiveness and improvement. The theory has four theoretical underpinnings, namely outcomes, leverage, intellectual capital, and social capital, which are related to desired educational outcomes and the financing strategies of an institution. In this context, while outcomes are indicators that measure cognitive and moral outcomes; leverage gauges the relation between teacher input and educational output. Thus, in conceptualizing intellectual capital, Hargreaves argues that instead of teachers employing too much effort and yielding little fruit, effective schools concentrate on effective strategies allowing a large impact to result from relatively low effort (that is, working smarter not harder). Outstanding schools use combinations of high leverage strategies. Understanding school effectiveness involves exploring how high leverage works (Hargreaves, 2001).

In this context, this paper perceives the Capital Theory of School Effectiveness and Improvement as being appropriate in examining the funding related challenges facing effective implementation of free secondary education in public secondary schools in Kenya under the FDSE policy. The appropriateness of the theory in this paper is justified due to the fact that all the theoretical concepts - outcomes, leverage, intellectual capital, and social capital - have a bearing on the quality of education which in turn is dependent upon effective funding mechanisms. Needless to say, the desired outcomes of free secondary education policy are to eliminate all barriers related to education financing that facilitates provision of quality secondary education to every Kenyan child graduating from primary schools to secondary school in the country, regardless of gender, ethnic background, or socioeconomic status. Thus, using the theory, the paper seeks to profile the challenges that could hinder desired outcomes and creation of intellectual capital and social capital in public secondary schools under the current Free Secondary Education (FDSE) policy in Kenya.

\section{Research Methodology}

The paper used mixed methods involving quantitative data from intensive review of literature from secondary sources that included Government documents, education review reports on education, statistical abstracts and appropriation account documents; and primary data from interviews with a purposively selected sample of 148 respondents drawn from across various education stakeholders in Kisii Central District, Kisii County, Kenya. The literature review focused on free education policy issues, government funding trends as well as the alternative strategies being used to supplement funding mechanisms. The interviews with key respondents focused on emerging challenges as a result of the free education policies in educations and suggestions on the appropriate sources of funding to complement the FDSE policy initiatives in Kenya. The 
study generated both quantitative and qualitative data. The quantitative data was analyzed using descriptive and inferential statistics generated by the statistical package for social sciences (SPSS) computer package, version 20, and reported using frequency tables and graphical methods( Orodho,2012). The qualitative data was analyzed thematically and reported in direct quotes and in narrative form.

\section{The Main Sources of Funds under the FDSE Policy in Kenya}

\section{Results And Discussion}

The first objective was to find out the main sources of funds for free day secondary education in Kenya. Literature review indicates that the main sources of secondary education in Kenya include households and the government (Republic of Kenya, 2012, Odhiambo, 2012; Orodho, 2014). Other sources of funds are private sector, religious organizations, communities, Non-Governmental Organizations (NGOs), and development partners largely the donor community. The cost of secondary education borne by the government and households consists of salaries for teaching and non-teaching staff, bursary allocations capital investments, school fees, tuition and transport, amongst others (Orodho, 2014). Table 1 contains data on unit public spending on education in selected years.

Table 1: Unit public spending by level of education, 2005 to 2008

\begin{tabular}{|c|c|c|c|c|}
\hline Unit Cost & 2005 & 2006 & 2007 & 2008 \\
\hline Primary & 6,251 & 6,862 & 7,457 & 7,781 \\
\hline Secondary & 20,783 & 24,918 & 29,485 & 58,585 \\
\hline Technical & 24,651 & 32,302 & 43,474 & 55,318 \\
\hline Secondary as a percentage of Primary & 3.3 & 3.6 & 4.0 & 7.5 \\
\hline Technical as a percentage of Primary & 3.9 & 4.7 & 5.8 & 7.1 \\
\hline University as a percentage of Primary & 18.2 & 20.9 & 18.6 & 17.7 \\
\hline Primary as a percentage GDP per capita & 0.16 & 0.16 & 0.16 & 0,15 \\
\hline Secondary as a percentage of GDP per capita & 0.54 & 0.59 & 0.63 & 1.13 \\
\hline Technical a a percentage per capita & 0.64 & 0.76 & 0.92 & \\
\hline University as a percentage of GDP per capita & 2.94 & 3.37 & 2.94 & \\
\hline
\end{tabular}

Source: Appropriation Accounts, MPER, various, Republic of Kenya,(2012a)

Table 1 shows estimated government (recurrent) spending per student enrolled in the respective levels of education. Primary education public unit spending increased from Kshs.6,251 in 2005 to Kshs.7, 781 in 2008 at current prices. The unit public spending at secondary education (Kshs.58, 585) was 7.5 times that of primary education in 2008 and $1.13 \%$ of GDP per capita. The 2008 unit spending at secondary education level includes the annual free day secondary school per capita allocation to public schools across the country

The salient message portrayed with the data in Table 1 is that the Government of Kenya attaches a lot of emphasis in the development of basic education as reflected in the overall allocation of over 70 percent of the total educational expenditure for this level of education. In fact the primary education sub-sector has consistently been allocated about half of the funds budgeted for the education Ministry.

\section{The income sources in public day secondary schools in Kisii Central District}

The second objective focused on the various source of income which PDSS resourced in the study locale. This was significant because it was these sources which schools depended on to finance the resources in public schools. The researchers would also be able to establish the adequacy and reliability and trend of income amounts between 2005 and 2010. The results are contained in Table 2.

Table 2: Frequency of response on sources of income to schools

\begin{tabular}{lll}
\hline Source of income & Responses & Percentage \\
& Frequency & 33.3 \\
\hline Government & 36 & 32.4 \\
PTA/Parents & & 2.8 \\
Donors & 35 & 1.9 \\
School income generating activities & 3 & 9 \\
Sponsor & 2 & 25.9 \\
CDF & 1 & 2.8 \\
\hline LATF & 28 & 100.0 \\
\hline Total & 3 & 108 \\
\hline
\end{tabular}


Data from Table 2 indicate that the bulk of the sources of funds that sustain public secondary schools in Kisii Central comes from the Government and parents, with $33.3 \%$ of the funds provided by the government and $32.4 \%$ generated from PTA/Parents. The other notable source of funds is the Constituency Development Fund (CDF) contributing slightly over one quarter of the funds. The local Authority Trust Funds LATF and donors contribute a paltry $2.8 \%$ each towards sustaining education in the study locale.

Table 3 shows the amount collected from the various income sources in PDSS between 2005 and 2010. The figures in Table 3 are computed in thousands of Kenya Shillings.

Table 3 : Amount per income source in PDSS (2005-2010) in Ksh'000

\begin{tabular}{|c|c|c|c|c|c|c|c|c|c|c|c|c|}
\hline \multirow{2}{*}{$\begin{array}{l}\text { Income } \\
\text { sources }\end{array}$} & \multicolumn{2}{|l|}{2005} & \multicolumn{2}{|c|}{2006} & \multicolumn{2}{|l|}{2007} & \multicolumn{2}{|c|}{2008} & \multicolumn{2}{|l|}{2009} & \multicolumn{2}{|l|}{2010} \\
\hline & Amount & $\%$ & Amount & $\%$ & Amount & $\%$ & Amount & $\%$ & Amount & $\%$ & Amount & $\%$ \\
\hline Government & 0 & 0.0 & 1324 & 3.1 & 7360 & 16.5 & 95898 & 82.7 & 104020 & 79.4 & 114190 & 76.8 \\
\hline Parents & 30400 & 87.9 & 31845 & 74.6 & 32660 & 73.3 & 14909 & 12.9 & 18408 & 14.1 & 22818 & 15.3 \\
\hline $\mathrm{CDF} / \mathrm{LATF}$ & 2180 & 6.3 & 6325 & 14.8 & 2229 & 5.0 & 3100 & 2.8 & 5680 & 4.3 & 8150 & 5.5 \\
\hline Sponsor & 0 & 0.0 & 0 & 0.0 & 0 & 0.0 & 150 & 0.1 & 0 & 0.0 & 2000 & 1.3 \\
\hline IGAS & 2000 & 5.8 & 2500 & 5.9 & 1500 & 3.4 & 1200 & 1.0 & 1400 & 1.1 & 1600 & 1.1 \\
\hline Donations & 0 & 0.0 & 700 & 1.6 & 800 & 1.8 & 600 & 0.5 & 1500 & 1.1 & 0 & 0.0 \\
\hline Total & 34580 & 100.0 & 42694 & 100.0 & 44549 & 100.0 & 115857 & 100.0 & 131008 & 100.0 & 148758 & 100.0 \\
\hline
\end{tabular}

The data contained in Table 3 shows that in 2005, the major sources of income in the PDSS were parents constituting of $87.9 \%$ of the total followed by CDF constituting of $6.3 \%$ and Income generating activities constituting of $5.8 \%$. There was no income from government, sponsors and donations in that year. The trend was nearly the same in the subsequent years where the income from parents was $74.6 \%$ and $73.3 \%$ in the year 2006 and 2007, respectively. In the same period there was no contribution from sponsors.

There was a dramatic shift in 2008 and 2009 where the government finance shot up from $16.5 \%$ in 2007 to $82.7 \%$ in 2008 and $79.4 \%$ in 2009 . The contribution from parents dropped sharply from $73.3 \%$ in 2007 to $12.9 \%$ in 2008 and stagnated at slightly $14 \%$ in 2009 and 2010. The income sources show the diminishing contribution by parents and the increasing participation of the government. Before the introduction of FSE, parents and communities were playing a greater role in financing education but after the introduction of FSE the government contributions increased.

The objective was further investigated by testing the null hypothesis that:

$\mathrm{H}_{0} 1$ : There is no statistically significant difference between PDSS income sources at $\alpha=.05$ level of confidence. The findings were reported in table 4 .

Table 4 : Analysis of Variance model for income sources

\begin{tabular}{|c|c|c|c|c|c|}
\hline Sources of variation & $\begin{array}{|lll|}\begin{array}{l}\text { Type III } \\
\text { Squares }\end{array} & \text { Sum of } \\
\end{array}$ & $\mathrm{df}$ & Mean Square & $\mathrm{F}$ & Sig. \\
\hline Income sources & 1.388 & 5 & 2.776 & 5.183 & .002 \\
\hline Error & 1.607 & 30 & 5.356 & & \\
\hline Corrected Total & 2.995 & 35 & & & \\
\hline
\end{tabular}

The results carried in Table 4 indicates that there was a statistically significant difference within the income sources $(\mathrm{F}=5.183, \mathrm{df}=5, \mathrm{p}=.002)$ existed at $\mathrm{p}(<.05)$ level of confidence. Although the significant $\mathrm{F}$-value at .002 indicated that the entire regression model was statistically significant, the adjusted $\mathrm{R}^{2}=.374$ confirmed that the entire regression model explained only 37.4 percent of the variance in income sources. The implication was that 62.6 percent of the variance in income sources was unexplained by the regression model. This made the researchers to go further and find out the trends in PDSS projected and actual expenditure between 2005 and 2010.

Table 5 : Trend in PDSS Projected and Actual Expenditure.

\begin{tabular}{lllllll}
\hline Year & $\begin{array}{l}\text { Projected } \\
\text { Amount }\end{array}$ & $\%$ & $\begin{array}{l}\text { Actual } \\
\text { Amount }\end{array}$ & $\%$ & $\begin{array}{l}\text { Deficit } \\
\text { Amount } \%\end{array}$ \\
\hline 2005 & 48404 & 100.0 & 39594 & 81.8 & 8810 & 18.2 \\
2006 & 52274 & 100.0 & 42812 & 81.9 & 9462 & 18.1 \\
2007 & 61649 & 100.0 & 50209 & 81.4 & 11440 & 18.6 \\
2008 & 108185 & 100.0 & 94033 & 86.9 & 14152 & 13.1 \\
\hline
\end{tabular}


Alternative Sources of funding for Free Day Secondary Education (FDSE) in Public Schools in...

\begin{tabular}{lllllll}
\hline 2009 & 128778 & 100.0 & 110204 & 85.6 & 18574 & 14.4 \\
2010 & 148915 & 100.0 & 132669 & 89.1 & 16246 & 10.9 \\
\hline
\end{tabular}

Source: Ministry of Education EMIS (Republic of Kenya, 2005 to 2010)

Data from Table 5 shows that the actual expenditure and deficit in PDSS in 2005 was $81.8 \%$ and deficit of 18.2\%. In 2006 the actual expenditure was $81.9 \%$ while deficit was $18.1 \%$. In 2007 the actual was $81.4 \%$ and deficit was $18.6 \%$. In 2009 the actual was $85.6 \%$ and deficit was $14.4 \%$ while in 2010 the actual was $89.1 \%$ and deficit was $10.9 \%$. The data shows that the deficit declined with the contributions from the government in 2008 when the government introduced FSE. The question was further investigated using the hypothesis that there is no significant relationship between projected and actual expenditure in education between 2005 and 2010. The data in Table 5 indicates that the trend of projected and actual expenditure has been nearly consistent ranging from a deficit of $18.6 \%$ in 2007 to $10.9 \%$ in 2010 . On average, the mean deficit over the years was $17.5 \%$.

It was felt prudent to test the second null hypothesis that:

$\mathrm{H}_{02}$ : There is no significant relationship between projected and actual expenditure in PDSS.

A correlation between projected and actual expenditure was done using spearman rank correlation coefficient and yielding a strong correlation coefficient of $\mathrm{r}=0.999$. The actual correlation model over the years on projected expenditure and the years yielded $\mathrm{R}^{2}=0.999$, which is statistically significant at $0.05 \%$ level of significance. The model explains $99 \%$ of the variance in expenditure.

\section{The reliability and adequacy of the income sources}

The third objective was to assess the extent to which the various income sources were reliable and adequate to sustain the quality of learning in PDSS. To determine the reliability and adequacy of income sources, a four point Likert scale was developed for this purpose. Table 6 presents information on the reliability of income sources. In the Likert scale, 1 represents 'extremely reliable', 2 represents 'very reliable', 3 represents 'reliable', and 4 represents 'not reliable'.

Table 6 shows that $58.8 \%$ of the respondents indicated that income from parents were unreliable while $41.2 \%$ indicated that income from parents was reliable. The researcher found that parents were to pay levies like lunch, development fee and even extra fees. The head teachers indicated from the interview schedule that parents were to pay in cash or any kind in day secondary schools. Approximately $41.2 \%$ of the respondents reported that school funds from parents were reliable, while 58.8\% said that funds from parents were unreliable. Over three quarters of the respondents agreed that funds from donors were very reliable, $12.0 \%$ said that they were reliable while $80.0 \%$ said that they were unreliable.

Table 6 : Reliability of income sources to PDSS in Percentage

\begin{tabular}{|c|c|c|c|c|c|c|c|c|c|}
\hline \multirow{2}{*}{\multicolumn{2}{|c|}{$\begin{array}{l}\text { Source } \\
\text { income }\end{array}$}} & \multicolumn{2}{|c|}{ Extremely reliable. } & \multicolumn{2}{|c|}{ Very reliable } & \multicolumn{2}{|c|}{ Reliable } & \multicolumn{2}{|c|}{ Unreliable } \\
\hline & & Freq. & $\%$ & Freq. & $\%$ & Freq. & $\%$ & Freq. & $\%$ \\
\hline Parents & & 0 & 0.0 & 0 & 0.0 & 15 & 41.2 & 21 & 58.8 \\
\hline Donors & & 0 & 0.0 & 3 & 8.0 & 4 & 12.0 & 29 & 80.0 \\
\hline IGAS & & 0 & 0.0 & 0 & 0.0 & 4 & 10.0 & 32 & 90.0 \\
\hline Sponsors & & 0 & 0.0 & 0 & 0.0 & 9 & 25.0 & 27 & 75.0 \\
\hline $\mathrm{CDF}$ & & 0 & 0.0 & 2 & 5.9 & 13 & 35.3 & 21 & 58.8 \\
\hline PTA & & 0 & 0.0 & 1 & 2.9 & 17 & 48.6 & 17 & 48.6 \\
\hline
\end{tabular}

Ten percent of the respondents reported that funds from school income generating activities / sources were reliable, while $90.0 \%$ said that they were unreliable. One quarter of the respondents reported that school funds from sponsor were reliable while $75.0 \%$ reported that they were unreliable. Approximately 5.9\% of respondents reported that funds from $\mathrm{CDF}$ were very reliable, $35.3 \%$ said that they were reliable while $58.8 \%$ responded that they were unreliable. About $2.9 \%$ of the respondents reported that funds from PTA were very reliable, $48.6 \%$ said that funds were reliable while $48.6 \%$ reported that funds from PTA were unreliable. From the interview schedule, the PTA chairpersons reported that $11.4 \%$ of respondents agreed that they were adequate while $88.6 \%$ disagreed.

On the adequacy of FSE, $8.8 \%$ of the headteachers agreed that FSE is adequate while $91.2 \%$ disagreed from the interview schedule administered to them. On the reasons of the inadequacy of FSE, $2.9 \%$ of respondents cited that the government does not provide for inflation hence incomplete projects, while $97.1 \%$ pointed out that high prices of goods is the reason for inadequacy of FSE. Table 8 shows the responses on the adequacy of income sources. 
Alternative Sources of funding for Free Day Secondary Education (FDSE) in Public Schools in...

\begin{tabular}{|c|c|c|c|c|c|c|c|c|}
\hline \multirow[t]{2}{*}{ Source of income } & \multicolumn{2}{|c|}{ Very adequate } & \multicolumn{2}{|c|}{ Adequate } & \multicolumn{2}{|c|}{ Fairy adequate } & \multicolumn{2}{|c|}{ Not adequate } \\
\hline & Freq. & $\%$ & Freq. & $\%$ & Freq. & $\%$ & Freq. & $\%$ \\
\hline Gok & 1 & 2.8 & 7 & 19.4 & 20 & 55.6 & 8 & 22.2 \\
\hline Parents & 0 & 0.0 & 3 & 8.4 & 16 & 44.4 & 17 & 47.2 \\
\hline Donors & 0 & 0.0 & 0 & 0.0 & 14 & 38.9 & 22 & 61.1 \\
\hline Harambee & 0 & 0.0 & 0 & 0.0 & 8 & 21.4 & 28 & 78.6 \\
\hline$C D F$ & 0 & 0.0 & 1 & 3.8 & 17 & 46.2 & 18 & 50.0 \\
\hline
\end{tabular}

Data in Table 8 shows that majority of respondents, constituting over 70 percent, were unanimous that contributions through harambee and income generating projects within the schools were inadequate to sustain FDSS policy in the study locale. Similarly, over half of the respondents were equally in agreement that the sources of funds through donors, parents' teachers associations (PTAs) and Constituency Development Funds (CDF) were inadequate to complement the free day secondary education initiative in the study locale. On the whole, it was apparent that the major sources of funding for the FDSE programme were the Government and parents, but these sources were not adequate. The general trend in income sources is exhibited in Figure 1.

Figure 1 : Trend of income sources from 2005-2010 in '000

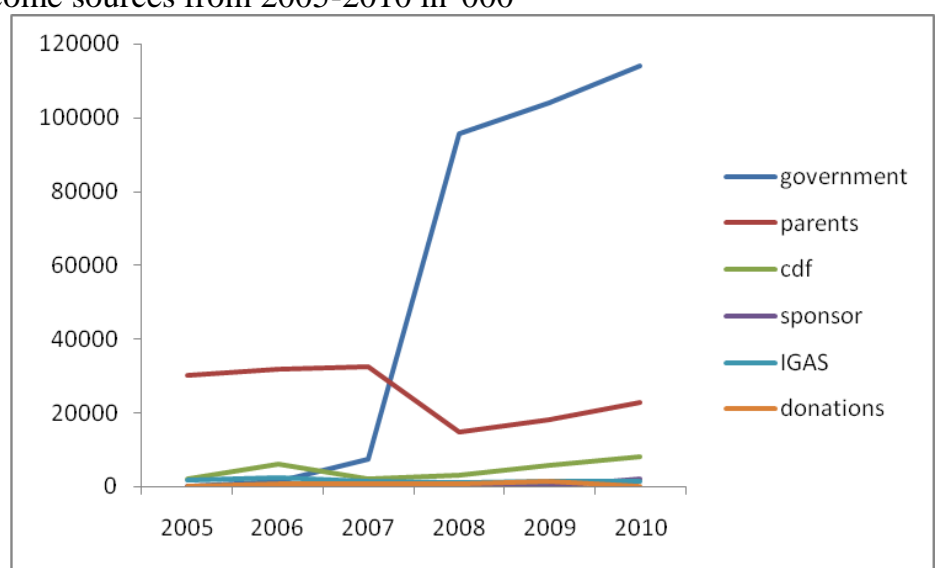

Source: Based on field Data

Figure 1 shows that there was a gradual increase in government contributions to PDSS. The rise was occasioned by the introduction of FSE in 2008.Figures in appendix K reflects that parents' contributions show a declining trend with a contribution of Ksh 30,400,000 in 2005 to Ksh 14,909,000 in 2008 and rising again to Ksh $22,818,000$ in 2010. The CDF/LATF contributions have been varying between Ksh 2,180,000 in the year 2005 and Ksh 8,150,000 in 2010. The contribution of the sponsors to school financing is normal with occasional contribution of Ksh 1,200,000 to Ksh 2,500,000 during the period under study. Schools have also been receiving donations ranging between Ksh 700,000 to Ksh 1,500,000 in 2008 and Ksh 2,000,000 in 2010. Income from IGAS has been varying between Ksh 1,200,000 to Ksh 2,500,000 during the period under study. Schools have also been receiving donations ranging between Ksh 700,000 to Ksh 1,500,000 during the period under study. All these indicated that the major sources of income to PDSS are the government and the parents. There is need to resource more funds from the other income sources. Generally figure 4.2 indicates that there was an increasing trend in annual income from the government and a decreasing trend on the other income sources to PDSS between 2005to 2010 .

Table 9 shows the projected, actual and deficit in annual expenditure in PDSS between 2005 and 2010.

Table 9 : School Income expenditure in PDSS in Kshs'000 2005-2010

\begin{tabular}{llll}
\hline Year & Projected & Actual & Deficit \\
\hline 2005 & 48404 & 39594 & 8810 \\
2006 & 52274 & 42812 & 9462 \\
2007 & 61649 & 50209 & 11440 \\
2008 & 108185 & 94033 & 14152 \\
2009 & 128778 & 110204 & 18574 \\
2010 & 148915 & 132669 & 16246 \\
\hline
\end{tabular}


From table 9 it is evident that all PDSS had a deficit in their expenditure. In 2005 the projected expenditure was Ksh 48,404,000; the actual was Ksh 39,594,000 with a deficit of Ksh 8,810,000. In 2006, the projected expenditure was Ksh 52,274,000, actual Ksh 42,812,000 with a deficit of Ksh 9,462,000. In 2007 the projected expenditure was Ksh 61,649,000, actual Ksh 50,209,000 and deficit was Ksh 11,440,000. In 2008, the projected was Ksh 108,185,000 actual was Ksh 94,033,000 and deficit of Ksh 14,152,000. In 2009 the projected was Ksh 128,778,000, actual Ksh 110,204,000 and deficit of Ksh 18,574,000. In 2010 the projected was Ksh 148,915,000 actual Ksh 132,609,000 and a deficit of Ksh 16,246000. All these indicated that there is a rising trend in projected and actual expenditure in PDSS. It also shows that there is an increasing trend in deficit in all schools and consequently the quality.

This hypothesis was tested by using the regression analysis and it was shown that income and expenditure are highly correlated( $\mathrm{r}=.993)$. The hypothesis that there is no statistically significant difference between income and expenditure was tested using the ANOVA which revealed that the relationship is significant. $(\mathrm{P}<0.05)$.

From the foregoing, it is evident that financing of education underlies the themes of the current education policy of quality access and efficiency. However, the spending on education is notably low at $16 \%$ (233.1billion) of the spending in the years 2012-2013. The ambitious plan of free primary education (FPE) increased the number of the pupils completing primary education and failure to expand secondary education will compromise quality and consequently jeopardize economic recovery and development.

In the present study, the government and parents are the main sources of revenue to public day secondary schools, while donors, IGAS, Sponsors, CDF/LATF indicate insignificant and highly fluctuating revenue. Data from the present study gave an accurate contribution of each source of revenue. In the present study, the revenue from the income sources is inadequate and unreliable to meet the corresponding financial needs at secondary school level. The income trend indicated quantitative increase of the government revenue from 2008 and declining trend by parents. Prior to 2008, parents' contribution was higher than the other sources of income.

The findings concur with KIPPRA (2006) that the costs of provision and expansion of quality secondary education have been escalating while resources for secondary education have been dwindling. The report projected the enrollment in secondary education to rise from 0.92 million in 2004 to 2 million and 2.7 million students by 2010 and 2015 respectively. The report further concurs with the present study that the main sources of secondary school funding are households and the government while the other sources of funds include private sector, religious organizations, NGOs and development partners. Public sources mainly fund teachers' personal emoluments and bursary to students, while household meet cost for provision of suppliers and equipment, operations, maintenance, repair and physical infrastructure. Whereas earlier studies indicate projections of enrolment and costs the present study is a representative accurate sample of educators (principals) reporting on their individual schools. All the principals reported that the income sources were inadequate and unreliable.

Resources for schools can be raised in a variety of ways but the major sources of funding should be based on sources that generate stable and growing revenue to schools. Sources that generate small and highly fluctuating revenues are not desirable for supporting the major operational expenses of schools. With the increasing demand for secondary school as a result of FPE programme, it is becoming increasingly important to improve programs of income sources that reduce the financial barriers to secondary schooling.

Mbelle (2008) reporting on a research on educational quality postulates that increasing access to education is only one aspect of addressing human resources capacity. It is importance to ensure high quality cognitive achievement, skills, values are attained. Quality aspects in education cover such issues as adequacy of having and teaching resources, which is a function of finances.

In this study, the contribution of parents towards meeting the costs of public day secondary schools were fairly inadequate and hence not capable of meeting the financial requirements of most schools. The finding agreed with that of Ogeta (2004) who found out that in South Nyanza, Kenya parents contributions towards meeting the costs of upper primary education were below what each of them expected to pay, the study attributed this to low average annual income per parent from their occupations. Similarly, in this study poor home background has contributed as a cause of parents' inability to pay for learning. It was also found in this study that Donors as a source of funding PDSS was $100 \%$ inadequate. Most schools did not seek donor support due to level of information by principals on donors who can support the education programme.

In this study, "Harambee" as a source of funding was found to be inadequate. This concurred with study findings of Ogachi (2002) on community financing of primary schooling in Kenya and its implications on quality in Kajiado and south Kisii Districts. The study established that community financing led to deterioration in quality of both physical facilities and learning. This was attributed to poor social economic background. The harambee though is being initiated by the schools, not one schools has used it to raise money for education. The current government policy of providing funds to schools has discouraged this model of financing education.

In this study, the IGAS as a source of income was also found to be inadequate. This finding agrees with the findings of Ho Ming $\mathrm{Ng}^{\prime}$ (2000) who in his study pointed out that: the ability of schools to create income 
positively correlates to the schools status. It was established that high status schools engaged in agricultural based IGAS. The study further pointed out that high status schools normally make profits because they are supported by alumni, influential parents and large enterprises. In this study it was established that most PDSS in Kisii Central have the land size of between 1-2 acres which is not enough to engage in large scale agricultural production. The social economic status of the parents and community is low hence the contribution to schools income is low. The study established that schools initiative supplement finances of secondary education.

These findings also concurred with that of Getange (2005) who found out that in Kisii Central District secondary schools cultivated beans, coffee, Napier grass besides dairy farming and poultry keeping. It is evident from this study that none of the schools have modern facilities like swimming pools, halls and school buses for hire; hence the income from IGAS is insufficient and fluctuating. The study also found PTA as a source of income to be inadequate. This was attributed to poverty of the households.

In this study, the trend of income-sources over the years shows a gradual increase of the government contribution and decrease of the parents' contributions. The introduction of FSE in 2008 saw withdrawal of parents' support with the excuse that education is free. However, this is not the reality on financial demands. The income from other sources is minimal and shows a fluctuating trend.

The income and expenditure trend shows a deficit over the years. However, there is significant difference between income and expenditure. KIPPRA (2003) coheres with the study that the patterns and trends of education financing in Kenya is based on partnership between the state, household and communities. The FDSE is a new dimension on the depth and volume of government, community and household expenditure on education services.

\section{Conclusion And Recommendations}

In the present study, the government and parents are the main sources of revenue to public day secondary schools, while donors, IGAS, Sponsors, CDF/LATF indicate insignificant and highly fluctuating revenue. Data from the present study gave an accurate contribution of each source of revenue. In the present study, the revenue from the income sources is inadequate and unreliable to meet the corresponding financial needs at secondary school level. The income trend indicated quantitative increase of the government revenue from 2008 and declining trend by parents. Prior to 2008, parents' contribution was higher than the other sources of income. There is a strong relationship between projected and actual expenditure in PDSS. The trend of income sources shows a gradual increase of the government contributions and dwindling of the parents contributions. This is due to the relaxation of the parents due to the erroneous notion that the government is supposed to meet all the education costs. This has greatly contributed to colossal budget deficits in most public day secondary schools in the district. The schools have not also devised more sustainable modes of generating funds from income generating projects to relieve parents from the financial burden and also complement the funds from the government kitty.

Arising from the findings, the following policy recommendations were made:

1. Given that the financial sources in public day secondary schools are unable to meet the required facilities for enhancing quality education, the government should increase the amount disbursed to schools due to inflation and the high cost of living. The government contribution should be disbursed in time preferably before the start of the term to avoid delay in disbursements which led to financial strains that hinder quality achievement in PDSS. Also provide enough funds for quality assurance officers. All these are based on promises made by the Government of Kenya and documented in the Basic Education Act, 2013.

2. It was evident from the study that one from the government cannot meet costs of day secondary school education. Education will need to be supported through multi-sources. The parents should be encouraged to continue to support education and be sensitized on the need to provide the supplementary resources required in education.

3. It was evident from the study that the income provided to school does not provide enough money to purchase the necessary teaching and learning resources. This was due to the unreliable and inadequacy of the income sources. It was also evident from the study that the community financial support is declining due to FSE policy. The community involvement needs to be harnessed more to provide such support like land, contributions in kind for construction and through mobilizing of harambee contributions.

4. It was evident that schools have IGAS, however, their contributions are minimal and schools should be encouraged to venture into lucrative and enterprising ventures which can generate supplementary income namely; brick making, housing units within the school, hire land for crop and animal production, intensive gardening and keeping poultry. Schools can create production units with unit managers who can run the IGAS. Entrepreneurial education should be inculcated into the teaching profession.

5. It is evident from the study that the government is unable to meet the financial requirement of day secondary education. The study recommends that cost sharing as a method of financing education should be strengthened so as to enhance the quality of education. This can be done by involving the 
communities, holding harambee fundraisings and encouraging more participation by the beneficiaries of education.

\section{References}

[1]. Brookings Institutions. (2013).Towards universal learning: What every child should learn. Brooks. Brunner, J.S.(1961).The Act of Discovery. Harvard Educational Review, Vol . No. 311961.

[2]. Getange, K (2005). Institutional Initiatives in Supplementing the Financing of Secondary Education in Kisii District .Unpublished M.ED Thesis ,Maseno University, Kisumu, Kenya

[3]. Ho Ming $\mathrm{Ng}(2000)$. Creation of Income by school in China: a survey of selected Schools in Guangzhou. Educational Management Administration and leadership, vol.29(4)

[4]. KIPPRA.(2006), Draft Report on "Financing Sources for Achieving MDGs in Kenya: Domestic Resources, Dept and ODA". KIPPRA, Nairobi.

[5]. Mbelle, A.(2008). The Impact of Reforms on the Quality of Primary Education in Tanzania, Research Report , Dar-salaam

[6]. Ministry of Education.(2013). Facts Sheet on education in Kenya. Ministry of education. Education System Statics. EMIS.

[7]. Odhiambo. (2010). Task force on re-alignment of education to the Constitution 2010 and Vision 2030 and beyond. The Government of Kenya.

[8]. Njeru, E.H.N.\& Orodho,A.J.(2003). Financing education in Kenya: Policy options and way forward. Institute of policy analysis and research (IPAR). Nairobi , Discussion Paper No.037/2003.

[9]. Ogachi, I.O (2002).Community Financing of Primary Schooling in Kenya and its

[10]. Ogeta, N,O. (2004). The Contributions of Parents to the Cost of Upper Primary Education Implications for free primary Education: A Case Study of South Nyanza.,Unpublished Ph.D thesis,Kenyatta University,Nairobi, Kenya.

[11]. Ohba, A. (2009). Does Secondary Education Enable the Poor to Gain Access?, A Study from Rural Kenya, U.K Center for International Education.

[12]. Orodho A. J.(2009). Elements of Education and social science research methods. Nairobi. Kanezja Publishers.

[13]. Orodho A. J.(2012). Techniques of writing proposals and reports in education and social sciences. Nairobi. Kanezja Publishers.

[14]. Orodho, J. A. ,Waweru,P.N,.Ndichu,M \& Nthinguri, R. (2013).Basic education in Kenya: Focus on strategies applied to cope with school-based challenges inhibiting effective implementation of curriculum. International Journal of Education and Research. Vol.1.No.11 Novembeer20113. Pp1-20 www.ijer.com

[15]. Orodho, J. A. (2014).Policies on free primary and secondary education in East Africa: Are Kenya and Tanzania on course to attain Education For All (EFA) by 2015?.International Organization of Scientific Research (IOSR) Journal of Humanities and Social Sciences (IOR-JHSS).Vol.19, Issue1, Ver,V (Jan 2014) pp11-20 www.iosrjournals.org .

[16]. Republic of Kenya. (2005a).) Sessional Paper No. 1 on Policy Reforms for Education, Training and Research: Meeting the Challenges of Education Training and Research in the $21^{\text {st }}$ Century. Ministry of Education, Science and Technology (MOEST Nairobi: MOEST

[17]. - ------(2005b). Kenya Education Sector Support Programme 2005 - 2010: Delivering Quality Education and Training to All Kenyans. Nairobi: MOEST.

[18]. ----.(2010a). The Constitution of Kenya, 2010. The Attorney General. Nairobi.

[19]. ------(2010b).Child friendly Schools Manual. Ministry of Education. Nairobi.

[20]. ------(2012a).Sessional Paper No.14 of 2012 on realigning education and training to the Constitution of Kenya 2010 and Vision 2030 and beyond. Ministry of Education Science and Technology. Nairobi. Kenya.

[21]. ------(2012b).A Policy Framework for re-aligning education to the Constitution 2010 and Vision 2030 and beyond.

[22]. -----(2013). The Basic Education Act 2013 No.14 Of 2013. Nairobi.

[23]. Republic of Kenya/UNICEF( 2012).Education for All (EFA) End of Decade Assessment (2001-2010). Ministry Of Education and INICEF. Nairobi.

[24]. UNESCO (2005a): EFA Global Monitoring Report 2005: Education for All, The Quality Imperative, UNESCO, Paris

[25]. UNESCO. (2005b). Education For All (EFA) Global Monitoring Report. UNESCO, Paris. United Nations (UN). (2004). Millennium development goals: Progress report 2004. Available at www.un.org/millenniumgoals/mdg2004chart.pdf. Retrieved January $25^{\text {th }} 2010$

[26]. United Nations. (2005a): MDG Status Report for Kenya for 2005, UN

[27]. ------- (2005b): UN Millennium Project, Task Force on Education and Gender Equality

2005 . (2012). Youth and Skills: Putting Education to work. EFA Monitoring Report.

[29]. ------(2013). A New Global Partnership: Eradicating Poverty and Transform Economy through Sustainable Development. The Report of the High-Level Panel of Eminent Persons on the Post- 2015 Development Agenda. The United Nations. 